\title{
Byen - forum for fysisk aktivitet
}

Af Thomas Skovgaard og Jens Troelsen

\section{Gladeligt er det, at ...}

Der er solid dokumentation for, at fysisk aktivitet kan forebygge en række sygdomme og fremme almen trivsel og sundhed. Fysisk aktivitet spiller blandt meget andet også en markant rolle i behandling af det, som benævnes metabolisk syndrom - en samlebetegnelse for en række stofskifteforstyrrelser. ${ }^{1}$

De sundhedsmæssige gevinster, der opnås via fysisk aktivitet har såvel fysiologiske, psykologiske som sociale effekter. De fysiologiske effekter er for eksempel mindre risiko for udvikling af hjerte-karsygdomme, fedme og type 2 diabetes. ${ }^{2}$ Blandt de psykologiske effekter er en mindre risiko for eller en bedre håndtering af negative tilstande som stress og depression. De sociale aspekter kommer til udtryk ved en positiv sammenhæng mellem det at være fysisk aktiv og udvikling af anvendelige sociale kompetencer og forankring i diverse typer af sociale netværk. Dertil kommer, at der er en vis sammenhæng mellem at være fysisk aktiv og en i øvrigt sund adfærd $\mathrm{i}$ form af eksempelvis indtagelse af ernæringsrigtig kost, afståelse fra rygning og valg af fritidsbeskæftigelser. ${ }^{3}$

Kort sagt er der altså belæg for, at fysisk aktivitet er godt for krop og sjæl. En række resultater synes ligeledes at kunne dokumentere fysisk aktivitets fremmende effekt på forhold som selvværdsfølelse, socialt velbefindende og oplevelse af overskud. ${ }^{4}$

\section{Problemet er, at...}

Mange ikke bevæger sig nok til at sikre helbredsmæssige gevinster. Tendensen er særlig tydelig blandt den voksne del af befolkningen, men spores ligeledes blandt børn og unge. For voksne europæere viser en af de seneste opgørelser eksempelvis, at kun fire ud af ti dagligt tager en gåtur på mere end ti minutter. I den samme skala markerer to ud af ti modsat, at de aldrig slentrer i blot ti minutter om dagen. ${ }^{5}$

Holder vi os til Europa, fremgår det af andre undersøgelser, at en betragtelig andel af den voksne europæiske befolkning (over 15 år) ikke er fysisk aktiv 30 minutter om dagen, som den danske Sundhedsstyrelse og lignende nationale og internationale myndighedsinstitutioner finder anbefalelsesværdigt for at sikre et godt helbred. ${ }^{6}$ Så vidt vides er der ikke offentliggjort lignende tværnationale oplysninger om, hvor stor en andel af de europæiske børn og unge, der når op på den anbefalede én times motion om dagen. Data fra det såkaldte HBSC-projekt (Health Behaviour in School-aged Children) antyder dog, at også blandt den yngste generation af europæere er fysisk inaktivitet et udbredt fænomen. På baggrund af en analyse af materiale fra Socialforskningsinstituttet slår socio$\log$ Knud Larsen fast, at $11 \%$ af de danske børn og unge i alderen 7-15 år ikke er motionsaktive i fritiden. ${ }^{7}$ 


\section{Så derfor ...}

Opfattes det fra mange sider som oplagt at fokusere på fysisk aktivitet i fors øget på at gøre os mindre syge samt afkorte vanskelige perioder præget af dårligdom. Ligeledes opfattes fysisk aktivitet som væsentligt i mere bredspektrede indsatser, der ikke er rettet mod bestemte sygdomme eller helbredsmæssige tilstande, men derimod sigter på at styrke individets almene muligheder for og evne til at håndtere de risici og belastninger, som tilværelsen rummer.

Bestræbelserne på systematisk at inddrage fysisk aktivitet i det forebyggende og sundhedsfremmende arbejde er derfor inden for de seneste år taget til i intensitet og omfang - også i Danmark. I den nyligt fremlagte nationale handlingsplan mod svær overvægt omhandler omkring halvdelen af de i alt 66 anbefalinger fysisk aktivitet. ${ }^{8}$ I november 2003 skitserede regeringen en strategi for sundhedsfremme blandt børn og unge. Også her peges der på fysisk aktivitets afgørende betydning for forebyggelses- og trivselsinitiativer blandt befolkningens yngste grupper. ${ }^{9}$ I det seneste nationale folkesundhedsprogram Sund hele Livet fra 2002 indgår fysisk aktivitet i forebyggelse af syv ud af otte prioriterede folkesygdomme. ${ }^{10}$ I Sund hele Livet programmet lyder den overordnede målsætning angående fysisk aktivitet: »Antallet af fysisk aktive skal øges markant, og fysisk aktivitet skal være en naturlig del af hverdagen «. ${ }^{11}$ Denne ambition er for så vidt den samme som i Folkesundhedsprogrammet fra 1999, hvor ét af de i alt 17 prioriterede mål består i at $\emptyset$ ge »antallet af danskere, som... er fysisk aktive...dels gennem klar information, dels gennem lettilgængelige muligheder for sund levevis «. ${ }^{12}$

\section{Artiklens arinder}

Med de næunte politiske tiltag er de sundhedsmæssige mål og intentioner udstukket. Nye politiske skridt er således taget i bestræbelserne på at fremme fysisk aktivitet. Næste opgave er at realisere de formulerede visioner. Det er i den sammenhæng, at artiklen har sit ærinde.

Formålet er først at redegøre for faktorer, der har indflydelse på menneskets adfærd i forhold til fysisk aktivitet. I den forbindelse fokuseres der særligt på et emne, der de seneste år har fået markant øget bevågenhed - nemlig hvordan de fysiske rammer vi færdes i, direkte og indirekte befordrer og begrænser mulighederne for fysisk aktivitet. Dernæst, og som opfølgning på artiklens første del, præsenteres og diskuteres projektet $»$ Odense - Danmarks Nationale Cykelby«. Projektet er et konkret eksempel på, hvordan man kan indtænke de fysiske rammer i (sundheds)adfærden, hvor cykling som transportform spiller den centrale rolle.

\section{Determinanter for fysisk aktivitet}

I fors $\varnothing$ get på at systematisere diskussioner og unders $\varnothing$ gelser af hvilken betydning faktorer som eksempelvis biologisk køn, intelligens eller materielle levevilkår har for sundhedsadfærd, skelnes der ofte mellem såkaldte individuelle og miljømassige adfærdsdeterminanter. Denne skelnen anvendes også i litteraturen vedrørende forklaring og intervention i forhold til adfærd relateret til fysisk aktivitet og sundhed. ${ }^{13}$

De individuelle determinanter er de individbundne faktorer, der motiverer folk til at være fysisk aktive. I fors øget på at identificere afgørende individuelle determinan- 
ter for fysisk aktivitet er det blandt andet blevet fors $\emptyset \mathrm{gt}$ at udrede samspillet mellem viden, holdning og adfærd. På baggrund heraf er der udviklet metoder til at understøtte individets tro på, at vaner og rutiner står til at ændre, og at disse ændringer kan fastholdes over tid.

De miljфmassige determinanter drejer sig såvel om de fysiske rammer (situationsfaktorer) som sociale faktorer. En række større tværsnitsunders $\emptyset$ gelser indikerer, at de fysiske og sociale rammer, der omgiver og former individets dagligdag, er med til at bestemme, hvorledes en sundhedsadfærd som fysisk aktivitet kommer til udtryk. $^{14}$

Indtil for få år siden var fokus overvejende rettet mod at identificere mulige individuelle determinanter for fysisk aktivitet. Dette har bevirket en $\emptyset$ get forståelse af, at nogle mennesker er fysisk aktive, mens andre ingenlunde føler den samme trang eller i det mindste ikke vægter fysisk aktivitet særlig højt på deres personlige prioriteringsskala. Samtidig er det dog blevet mere klart, at der er behov for at vurdere, hvorledes de ydre forhold, som mennesker lever under, indvirker på de faktiske og oplevede muligheder for fysisk aktivitet. Udover at en sådan »rammetænkning « bidrager til at undgå den totale individualisering af ansvaret for livsstil - hvilket i negativ form kan føre til det meget omtalte »blaming the victim « syndrom ${ }^{15}$ - så synes denne tilgang også velegnet til at supplere de individorienterede interventionsstrategier på et punkt, hvor disse ofte kommer til kort - nemlig i bestræbelserne på at »få fat $\mathrm{i} \ll$ og udvikle virkningsfulde motionsstrategier for den inaktive eller mindre aktive del af befolkningen. Set i et forebyggelsesog sundhedsfremmeperspektiv er netop dette segment af befolkningen ekstra interessant. Det er nemlig dokumenteret, at de

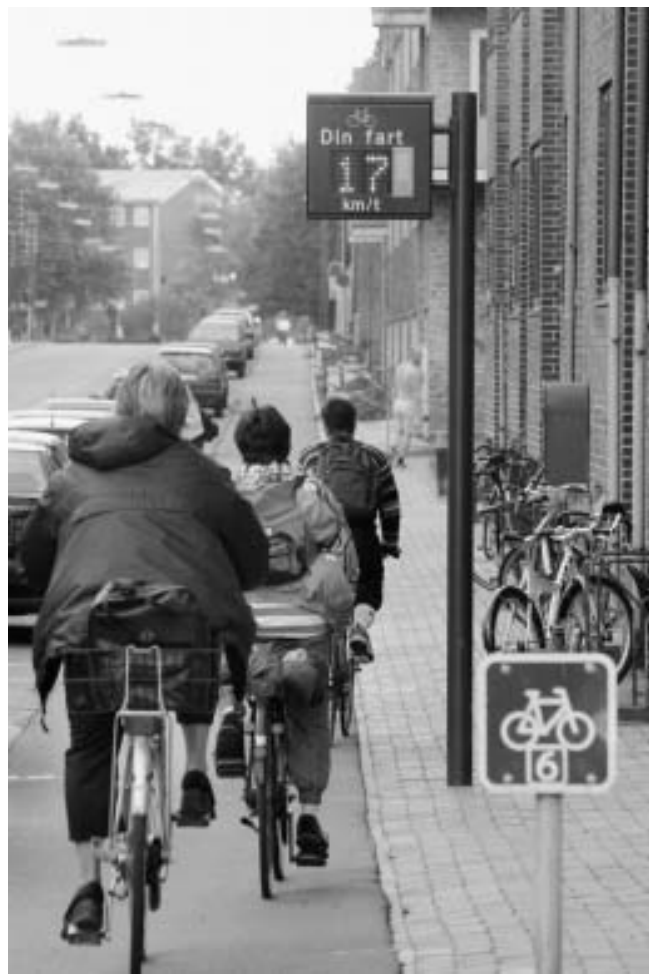

Langs to centrale indfaldsveje til Odense centrum er der opstillet hastighedsmålere på cykelstierne, der anviser rette fart for "grøn bølge" gennem trafiklysregulerede vejkryds.

mindst aktive får relativt mest ud af mere fysisk aktivitet. En række undersøgelser godtgør, at den største sundhedsfremmende effekt af mere fysisk aktivitet kommer ved at få gang i dem, som har et stillesiddende arbejds- og fritidsliv. Der er dog også god grund til generelt at højne befolkningens fysiske aktivitetsniveau, da hverdagen i stigende grad bliver fysisk inaktiv for stadig flere mennesker. ${ }^{16}$

Den mindre aktive eller inaktive gruppe er dog svær at få engageret. Først skal der skabes opmærksomhed omkring fordele ved fysisk aktivitet, herefter en selverkendelse af nødvendigheden af mere motion, 
efterfulgt af egentlig ændring og sluttelig fastholdelse af den ønskede ændring.

Hvad vi har brug for i den forbindelse er ikke at se bort fra det, vi ved om sundhedsfremme rettet mod enkeltindivider, men derimod at kombinere denne viden med fors $\varnothing \mathrm{g}$ på at tilrettelægge det, der ovenfor benævntes miljømæssige determinanter, således at de personbundne og de miljømæssige determinanter tilsammen stimulerer til fysisk aktivitet.

\section{Miljødeterminanter og byens fysiske rum}

I overensstemmelse med artiklens ærinde vil fokus i det følgende være rettet mod en underkategori af de miljømæssige determinanter, nærmere bestemt det fysiske rum. Det vil sige de fysiske omgivelser, hvori mennesker lever deres liv. Der kan i den forbindelse være tale om naturområder og parker, infrastrukturer som stier og veje eller arkitektur og landskaber, der tilsammen sætter et særligt præg på et bestemt område og dermed potentielt påvirker graden af fysisk aktivitet i positiv retning.

I de seneste år har der været en stigende interesse for at vurdere om intervention $\mathrm{i}$ de fysiske rammer og omgivelser, hvor vi færdes i forbindelse med arbejds-, hjemme- og fritidsliv, kan hjælpe til med at gøre flere mere fysisk aktive.

Sådanne bestræbelser kendes først og fremmest fra større byområder, hvor det med større eller mindre held (og entusiasme) er fors $\emptyset \mathrm{gt}$ at promovere specielt gang og cykling både som transport og ren fornøjelse. ${ }^{17}$

Den fundamentale grund til, at byen er i centrum - også når det handler om fysisk aktivitet som sundhedsfremmer - er den fortsatte urbanisering. Verdens befolknin- ger vandrer mod byerne. Halvdelen af menneskeheden bor allerede i større bysamfund og forventningen er, at dette tal vil stige til omkring $60 \%$ i løbet af de næste ca. 20 år. Fokuseres der som tidligere på Europa, er urbaniseringsgraden endog endnu højere. Dette bosættelsesmønster betyder ganske enkelt, at indsatser af sygdomsforebyggende eller sundhedsfremmende karakter har mulighed for at nå de største dele af en given befolkning, hvis indsatsen er rettet mod byboere.

Det kan søges at påvirke graden af fysisk aktivitet direkte ved at etablere og vedligeholde tilgængelige, bekvemme, sikre og indbydende motions- og idrætsfaciliteter. Det kan også mere indirekte fors $\emptyset$ ges at $\varnothing$ ge folks lyst til eller i det hele taget mulighed for at bevæge sig rundt på måder, der kræver mere fysisk aktivitet end det at sætte sig ind i en bil eller op på andre motoriserede transportformer.

Indretningen af byens beboelseskvarterer, placering og indretning af privat og offentligt byggeri, rekreative og grønne områders geografi og sammensætning samt den generelle infrastrukturs opbygning er eksempelvis med til at afgøre, om det overhovedet er muligt at integrere fysisk aktivitet $i$ dagligdagen. Væsentligt i den henseende er også, hvor godt byens forskellige elementer hænger sammen. En sammenhængende by er den, hvor man frit, forholdsvis hurtigt og sikkert kan bevæge sig rundt fra det ene punkt til det andet uden at skulle forcere mange forhindringer (eksempelvis i form af tætpakkede trafikknudepunkter og indfaldsveje) og tage adskillige omveje (grundet mangel på farbare transportveje $\mathrm{i} \gg$ fugleflugtslinie « mellem afgangs- og ankomststed). Skal den sammenhængende by tillige være den bevægelsesvenlige by må udgangspunktet for tilrettelæggelse af såvel bebyggelse som infrastruktur være mulig- 
heden for ikke-motoriserede transportformer kombineret med kollektiv trafik.

\section{Cyklen og byen}

Et lokalt eksempel på at gøre en by mere bevægelsesvenlig er det ministerielle og kommunale projekt »Odense - Danmarks Nationale Cykelby«. Projektet havde i perioden 1999-2002 som formål at forøge antallet af cykelture med $20 \%$ uden at gå på kompromis med trafiksikkerheden. Projektet var finansieret af Odense Kommune, Vejdirektoratet og Trafikministeriet med i alt 20 mio. kr.

Der er flere bevæggrunde for netop at fremme cyklisme i byen. Over en tyveårig periode er den distance, som danskerne gennemsnitlig transporterer sig, steget med $60 \%$. Væksten er hovedsagelig sket ved en stigning i biltrafikken. Bilen stod således for $80 \%$ af det samlede danske persontransportarbejde i $2001 .{ }^{18}$ Udviklingen i bilisme fører til en række fysiske, $\emptyset$ konomiske, $\varnothing$ kologiske og trafikale problemstillinger, og på sigt vil den megen tid brugt på stillesiddende transport givet have konsekvenser for sundhedstilstanden på befolkningsniveau.

Cykling har den egenskab, at den kan løse flere af disse problemstillinger samtidig. For det første er cyklen et transportmiddel, de fleste danskere har stiftet bekendtskab med. Cykling giver en større aktionsradius end det er tilfældet med gang, og forbedrer dermed markant trafikantens fremkommelighed og tilgængelighed til $\emptyset$ nskede destinationer. Cyklen er især anvendelig i større byer, hvor afstandene mellem diverse ærinder ofte er overkommelige. Godt $40 \%$ af samtlige ture, der bliver foretaget i Danmark, er under fire kilometer, hvor næsten halvdelen af disse ture foregår i personbil og kun 27\% på cykel. ${ }^{19}$
Der er således et stort uudnyttet potentiale. I tæt bytrafik vil det samtidig være tidsbesparende at bruge cyklen - både med hensyn til at komme hurtigere frem og finde parkering. Cyklen opfylder således et moderne krav om hurtig og effektiv mobilitet. Dernæst er ressourceforbruget i forbindelse med cykling begrænset - dog tærer cyklisten på kaloriekontoen, men det gør i de fleste tilfælde ikke så meget. I et bredt $\varnothing$ kologisk perspektiv er der i forbindelse med fremstilling af cykler og de efterfølgende reservedele tale om en belastning af miljøet, der er markant mindre end den, der finder sted, når der produceres motoriserede køretøjer. Dette er et gode på såvel lokalt som globalt niveau. For særlig de nære omgivelser er det endvidere af betydning, at cyklen ikke forurener eller støjer synderligt. Cykling bidrager på den måde til et mere rent og fredeligt bymiljø.

For det tredje kræver cyklen begrænset plads. Det mindsker udgifterne til både anlæggelse og vedligeholdelse af infrastruktur og forbedrer samtidig den trafikale fremkommelighed, hvilket er et plus især for større byer, hvor trafikophobning grundet flaskehalse i transportnetværket er et stigende problem. Set i forhold til anvendt areal kan cykler transportere næsten dobbelt så mange personer som busser og syvdobbelt så mange som personbiler.

Og endelig kommer dertil den fysiske aktivitet forbundet med transportformen. 30 minutters moderat fysisk motion hver dag, gerne fordelt i flere intervaller, har som nævnt gavnlig virkning på sundhedstilstanden og virker forebyggende i forhold til en lang række livsstilssygdomme. Alene brugen af cyklen kan opfylde disse kriterier, hvis turen til og fra arbejde eksempelvis er omkring fire kilometer. Et follow-up studie af 6.954 danskere understøtter det sundhedsgavnlige i at cykle. Personer, som ikke 
cyklede til arbejde, havde en 39\% højere dødelighed end cyklisterne. Justeret i forhold til andre risikofaktorer og anden fysisk aktivitet havde de, som cyklede til arbejde sammenlignet med dem, som ikke cyklede, en mortalitetsrate på $0,72 .{ }^{20}$ Cykling som transportform, der i unders $\varnothing$ gelsen gennemsnitlig var af tre timers varighed om ugen, synes således at have en betydelig indvirkning på forbedringen af hyppigt anvendte mål for befolkningens sundhedstilstand.

Cykling som transportform slår således flere fluer med et smæk. Transportformen giver effektiv mobilitet i større byer, belaster ikke miljøet, skaber renere og fredeligere byrum med god fremkommelighed, begrænser udgiftsposten til anlæggelse og vedligeholdelse af veje og bidrager tilmed til en forbedring af i første omgang cyklistens helbred. De samfundsmæssige udfordringer i forhold til global opvarmning, luftforurening, trafik og stigende udgifter til sundhedssektoren vil blive mindre, hvis cykling som transportform vandt frem på bekostning af de dominerende motoriserede transportformer. Transportøkonomisk Institutt i Norge har eksempelvis beregnet, at for hver nordmand, der tager cyklen til arbejde, vil det norske samfund årligt spare næsten $30.000 \mathrm{kr}$. Beregningen er sket ud fra en antagelse om, at en udbygning af cykelstinettet vil få flere til at vælge cyklen. Dette mindsker udgifter forbundet med sygefravær og anvendelse af sundhedsvæsenet samt mindsker omkostninger til bilinfrastruktur og hertil knyttede miljøforanstaltninger. Forfatteren bag de norske beregninger hævder, at de økonomiske gevinster ved at etablere gang- og cykelstier mindst vil være fire-fem gange så stor som udgifterne til at anlægge stierne. ${ }^{21}$

\section{De gode intentioner og den manglende virkning}

De objektive goder af cykling - og specielt sundhedsaspektet - har medført, at der fra politisk side er kommet større bevågenhed på at fremme cyklismen. Kombinationen af miljøhensyn, fremkommelighed, fysisk aktivitet og sundhed har skabt en større trafikpolitisk velvilje det seneste årti såvel i Danmark som i Europa.

Indsatsen har især været fokuseret på at fremme cykling som transportform på bekostning af bilisme. I forsøget på at sende rette signal har ministre med eller uden cykelhjelm derfor velvilligt sat sig i sadlen og ladet sig fotografere på cykelturen til og fra Christiansborg. På et mere handlingsorienteret plan førte det i 1999/2000 under den socialdemokratiske regering til udarbejdelse af en decideret national cykelhandlingsplan, der består af delene:

- På cykel i det 21. århundrede

- Fremme af sikker cykeltrafik - en strategi

- Idékatalog for cykeltrafik.

Daværende trafikminister, Jacob Buksti, mente med handlingsplanens tre dele, »at vi har lagt grunden til en bred debat om, hvor vi vil hen med cykeltrafikken i Danmark og hvordan vi kommer dertil. «22

På europæisk plan er de politiske vinde også skiftet til fordel for cyklisme. Projekterne ADONIS og WalCyng, og specielt rapporten Cycling: the way ahead for towns and cities udgivet af EU-Kommission i 1999 er udtryk for, at et holdningsskifte er ved at finde sted på transportområdet. ${ }^{23}$ Det skorter således ikke på gode intentioner, men til trods herfor har udviklingen i cyklisme de seneste mange år været for nedadgående.

På europæisk plan bliver kun 5\% af det 
samlede antal ture foretaget på cykel. Dette er bemærkelsesværdigt, i og med at omkring halvdelen af de ture, som foretages $i$ bil, er under fem kilometer. ${ }^{24}$ Det er altså ikke, fordi europæerne skal langt omkring, at cyklen får lov til at samle støv.

I Danmark, der sammen med Holland klart er i førertrøjen med hensyn til cyklisme, ${ }^{25}$ har cyklen de senere år også tabt terræn. På nationalt plan er der de sidste femten år sket et fald på 33\% i persontransportarbejdet foretaget på cykel. Tilsvarende er der i samme periode sket en forøgelse på $23 \%$ i persontransport foretaget i bil. ${ }^{26}$ Cyklen stilles $\mathrm{i}$ garagen, og typisk indkøbes familiens anden bil. I den henseende bliver cyklen snarere anskuet ved dens begrænsninger frem for dens kvaliteter.

Der kan opregnes flere grunde til denne udvikling. Udbygningen af vejnettet, herunder omfartsveje, amtsveje, motorveje og broer er væsentlige grunde til, at persontransportarbejdet med biler er steget. Udviklingen er gået i retning af, at danskerne transporterer sig længere på noget nær samme tid. Gennemsnitshastigheden for transportture foretaget i 1981 var på 29 $\mathrm{km} / \mathrm{t}$. Dette tal var i 1999 steget til 44 $\mathrm{km} / \mathrm{t}^{27}$ De infrastrukturelle forbedringer for biler har derfor haft deres virkninger. Eksempelvis er det muligt at bosætte sig stadig længere væk fra sin arbejdsplads.

Det danske Transportråd angiver dog mere grundlæggende årsager til den biltrafikale udvikling, hvor der skæves til de seneste årtiers totalt set gunstige økonomiske konjekturer. Velstanden er steget. Der er sket en større specialisering på arbejdsmarkedet, hvor kvinderne i stadig stigende grad også finder vej. Endelig er det således, at vi i fritiden har råd til at transportere os over større afstande. ${ }^{28}$

\section{Odense cykler}

De beskrevne udviklingstendenser på transportområdet var udgangspunktet for Odense Cykelbyprojekt. Formålet var at bidrage med idéer og afprøve nye tiltag i forsøget på at overflytte motoriserede trafikanter til brug af cyklen. Grunden til at Odense blev udnævnt som cykelby, skyldes byens i forvejen høje niveau. Siden 1976 har cykling været en væsentlig del af odenseansk byplanlægning. Ved projektets start i 1999 var der således anlagt $350 \mathrm{~km}$ cykelsti. ${ }^{29}$ Nationalt og i særdeleshed internationalt var den lokale cykelinfrastruktur på et meget højt niveau. For cykelbyprojektet drejede det sig derfor ikke så meget om at anlægge flere cykelstier, men i højere grad om at $\emptyset \mathrm{ge}$ fremkommeligheden for cyklister og generelt sætte fokus på kvaliteterne ved cykling som transportform. På den baggrund var Odense at regne som et laboratorium og demonstrationsprojekt, hvor flere samtidige initiativer skulle afprøves i bestræbelserne på at fremme cyklisme på højeste niveau efter et frivillighedsprincip.

Til det formål blev der iværksat i alt 48 delprojekter rettet mod alle aldersgrupper. Delprojekterne omfattede bl.a. udlån af cykeltrailere til børnehaver, som skulle demonstrere mulighederne for at transportere børn med cykel, skolevejskampagner, som satte fokus på skolebørns cykelvaner, og cykler til blandt andet hjemmeplejen og politiet, som viste cyklens erhvervsmæssige kvaliteter. En bred vifte af kampagner blev således lanceret for at skabe et mere positivt syn på cyklen og dens muligheder. Rækken af fysiske forbedringer sigtede mere bredt på at forbedre fremkommeligheden for og anvendelsen af cyklen. Eksempler herpå er anlæggelse af højresvingsbaner, så cyklisten føres uden om lysregulerede kryds, ha- 
stighedsmålere langs cykelstier, der anviser rette fart for »grøn bølge« gennem lysregulerede kryds, forbedrede cykelparkeringsanlæg til tyverisikring af cykler osv. Disse er blot enkelte eksempler på delprojekter, som havde til formål at overflytte motoriserede trafikanter til cykelbrug (for flere eksempler se www.cykelby.dk).

De mange delprojekter medvirkede til, at cykelbyprojektet opfyldte sin målsætning om flere cykelture foretaget i Odense Kommune. Korrigeret for eksterne faktorer skete der i den fireårige projektperiode en fremgang på de ønskede $20 \%$. Dette svarer til, at der i projektets forløb blev foretaget 35 mio. nye cykelture eller ca. 25.000 ekstra cykelture hver dag. Udviklingen i Odense går således imod de nationale tendenser, som fortsat viser et fald i cykeltrafikken i Danmark. Til trods for den markante stigning skete der samtidig et fald på $20 \%$ i antallet af cyklistulykker. Dette vidner muligvis om, at et større antal cyklister på gader og stier øger opmærksomheden blandt bilisterne og dermed mindsker sandsynligheden for, at cyklister bliver påkørt. Det kan endog være, at den $\varnothing$ gede koncentration af cykler har fået selv cyklisterne til at se sig bedre for og dermed undgå uheld..$^{30}$

Det er således muligt ved en intensiv, massiv indsats at overflytte motoriserede trafikanter til cyklen. Godt halvdelen af de nye cykelture stammer fra bilister, der frivilligt har foretaget et skift. De seneste trafikmålinger viser, at odenseanerne i 2003 benytter cyklen på hver fjerde tur. ${ }^{31}$

Odense Cykelbyprojekt var et forsøg på at afvikle en række samtidige initiativer med henblik på at opnå synergieffekt mellem delprojekterne. Hvorvidt det lykkedes har ikke været muligt at spore i den samlede evaluering, men faktum er, at tilfredsheden med Odense som cykelby, været tiltagende i projektet fireårige periode. I foråret 2003 kan $82 \%$ af borgerne således tilslutte sig opfattelsen, at Odense er en god by at være cyklist i. ${ }^{32}$ Kampagnevirksomhed har bidraget til den positive udvikling, men de fysiske forbedringer anføres i den sammenhæng som havende størst betydning. I evalueringen af projektet fremhæves den forbedrede fremkommelighed med grønne bølger og smutveje samt de bedre og mere tyverisikrede cykelparkeringsfaciliteter. Dette understreger, at kampagnevirksomhed har effekt i forhold til at skabe synlighed og kendskab til givne forhold, men hvis det skal føre til deciderede adfærdsændringer, stiller det krav om fysiske rammer, der kan underst $\varnothing t t e$ de individuelle valg.

Internationalt scorer Odense højt. I en undersøgelse foretaget af BYPAD (BicYcle Policy AuDit), der er et EU-finansieret benchmarking program, som skal sikre kvalitetsstyring af cykelpolitikken i Europa, er Odense den by, der blandt 21 byer får højeste karakter i 2004. Programmet består af 35 punkter omhandlende aspekter som brugerbehov, styring, formuleret politik, ressourcer, infrastruktur, kommunikation og uddannelse, målgrupper og partnerskab, supplerende aktiviteter samt evaluering og opfølgning. Målt på disse parametre opnår Odense $84 \%$ af den maksimale score, hvilket er nær det dobbelte sammenlignet med byer som Bruxelles, Eindhoven og Hillerød. Odense er således på en lang række punkter et godt eksempel til efterfølgelse i bestræbelserne på at fremme cyklisme på bekostning af bilismen - og dette vel at mærke efter et frivillighedsprincip.

På såvel nationalt som internationalt niveau lader et højt profileret og velfinansieret projekt som »Odense - Danmarks Nationale Cykelby« sig dog ikke bare kopiere. Dels vil det kræve store ressourcer, der ofte kun med største vanskelighed kan ind- 


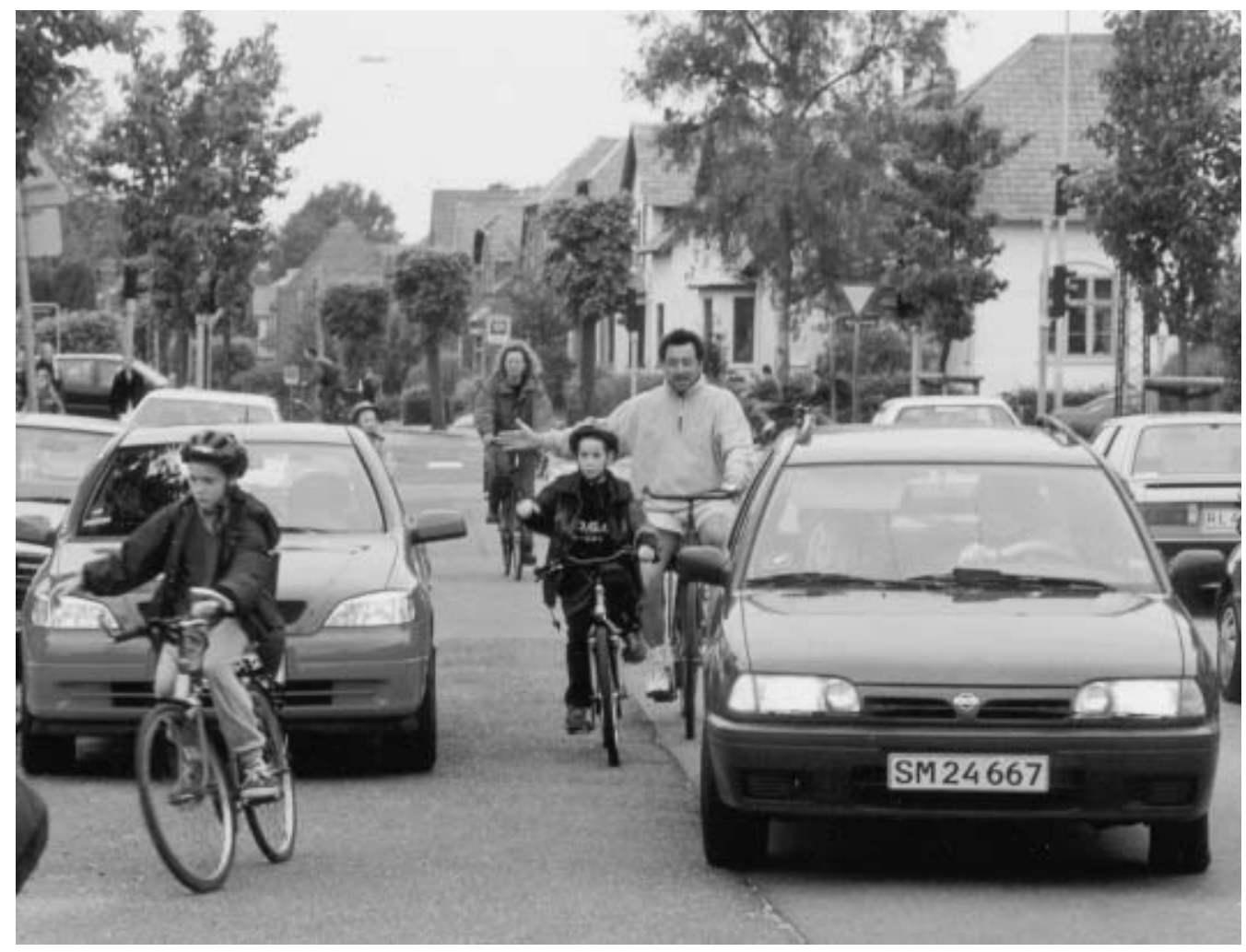

Ved en rakke vejkryds er der anlagt højresvingsbaner, der behoendigt fører cyklisten uden om trafiklysregulering og фvrige afventende trafikanter.

skrives i kommunale driftsbudgetter, dels vil en massiv indsats kræve politisk opbakning. Endelig kræves en form for folkelig opbakning, hvor cyklen faktisk opfattes som et reelt, brugbart transportmiddel. Cykelbyprojektet kan dog virke som flagskib, hvor det er muligt at hente inspiration, og som et synligt bevis på, at sundhedsfremme for større befolkningsgrupper er realiserbart via det, som ovenfor kaldtes indirekte tilgange.

\section{Cyklismens rolle}

I et moderne samfund med krav om mobilitet og fleksibilitet kan cyklen langt fra indfri alle transportbehov. Der er en $\varnothing$ vre grænse for, hvor langt og hvor meget man kan transportere sig på cykel. I en by som Odense synes grænsen dog endnu ikke at være nået. Inden for kommunegrænsen vil transportbehov til skole, indk $\varnothing b$, uddannelse og arbejde kun sjældent overstige, hvad der for de fleste synes overkommeligt på cykel. Afstande mellem bopæl og øvrige ærinder er derfor først og fremmest at betragte som oplevede størrelser, der synes uoverstigelige, hvis de negative cykeloplevelser har været flest. Da vil bilen være en mere magelig, men ofte ikke hurtigere transportform.

I Danmark, hvor tilgængeligheden af trafiksikre cykelstier generelt er stor, vil næste skridt derfor være at anlægge forbin- 
delseslinier, der i højere grad understøtter den positive cykeloplevelse. Eksempelvis cykelruter adskilt fra biler og andre motoriserede transportmidler eller genveje gennem parker og grønne områder. En anden metode, der fors $\emptyset$ gsvis er afprøvet, er at vende vigepligten ved vejkrydsende cykelstier, så det i stedet er biler, der skal holde tilbage for cyklister. Et mere radikalt træk ville være - som det er gjort i centrum af den hollandske by Groningen - at anlægge hele vejnettet med udgangspunkt i cyklisme. Her er biler forvist til såkaldte siveveje, så cyklister og fodgængere frit kan komme frem, mens taxaer og lastbiler ad bagveje må køre til deres destination.

For størstedelen af Europa kan sådanne innovative skridt slet ikke komme på tale. I Storbritannien og i Middelhavslandene drejer det sig først og fremmest om overhovedet at gøre cykling som transportform mulig. Under de nuværende omstændigheder er det med livet som indsats. Kun sjældent og udelukkende i yderste nødstilfælde overvejes det at sende børn ud i trafikken på cykel. Med det udgangspunkt bliver cyklen aldrig et reelt transportmiddel, men forbeholdt fanatikere og vovehalse. For lande uden for den skandinaviske og nordeuropæiske region vil et første skridt derfor være at anlægge et sammenhængende, trafiksikkert cykelstinet.

Den italienske by Ferrara er et godt eksempel på, at by- og trafikplanlægning er afgørende i bestræbelserne på at fremme cyklisme og dermed også graden af fysisk aktivitet blandt større befolkningsgrupper. I kontrast til de omkringliggende større italienske byer har Ferraras 134.000 indbyggere 110.000 cykler, og $31 \%$ af turene inden for bygrænsen foretages på cykel. Dette niveau er først og fremmest opnået ved at forbedre de fysiske rammer for cyklisme. Kampagnevirksomhed er kun i mindre skala taget i anvendelse. I Ferrara har det således været muligt at etablere en egentlig cykelkultur i et land, hvor cykling som transportform overvejende er forbundet med lav social status. ${ }^{33}$

\section{Byens rum og fysisk aktivitet}

Den fundamentale målsætning for projekter og initiativer nævnt i denne artikel er at anspore flere til at blive fysisk aktive ved at muliggøre et reelt valg mellem en række transportformer i byens rum. I almindelighed betragtes det som positivt at tilvejebringe valgmuligheder og fremme bevægelsesformer opfattet som sunde og gode for helbredet. Fronter opstår dog så snart eksempelvis forskellige transportbehov og - $\varnothing$ nsker skal prioriteres indbyrdes. Det er således en fortløbende diskussion, hvorledes de bløde trafikanter samt den kollektive trafik får mere plads, samtidig med at bilisterne sikres rimelig fri mobilitet. I forsøget på at opnå »fælles fodslag « understreges ikke sjældent fra kompromissøgende hold, at det at anvende byens rum som ramme for forebyggende og sundhedsfremmende indsatser ikke først og fremmest handler om at »få bilen ud byen«, men om at styrke mulighederne for at indbefatte fysisk aktivitet som en naturlig del af dagligdagen. Nogle gange lykkes den slags fors $\emptyset \mathrm{g}$ på konsensusdannelse faktisk - ikke mindst fordi der efterhånden er rimeligt belæg for samt voksende politisk erkendelse af, at der er behov for at sætte ind på såvel individuelle som strukturelle niveauer for at $\varnothing \mathrm{ge}$ befolkningens lyst til og muligheder for fysisk aktivitet.

Hermed understreges det på ny, at sundhed og motion i høj grad er et kollektivt anliggende, der kræver politisk handling og intervention. Denne politiske handlekraft skal dog ikke isoleret udgå fra en bestemt 
gren af den offentlige forvaltning, et bestemt ministerium eller en særegen kommission. Sundhed og motion er derimod et tema, som bør gå på tværs af adskillige sektorer og inddrages $i$ en bred vifte af politiske beslutninger. Afgørende er det, at denne type af inddragelses- og beslutningsprocesser giver plads til påvirkning fra aktører, der ikke direkte repræsenterer interesser i de formelle beslutningssystemer. Yderligere bør det være sådan, at rimeligheden og betydningen af tiltag med fokus på fysisk aktivitet altid vurderes i forhold til initiativer, som er møntet på andre vigtige faktorer for sundhed så som rygning, dårlig ernæring, alkohol, social isolation, absolut og relativ fattigdom etc.

Der er langt igen før en idealsituation som den ovennævnte kan erklæres for realiseret. For så vidt angår ønsket om tværsektorielt samarbejde, har det været på den internationale sundhedspolitiske dagsorden i over tyve år, uden at det tilsyneladende har resulteret i mere varige løsningsmodeller. ${ }^{34}$ En afgørende grund til denne langmodighed blev allerede dokumenteret for mere end 30 år siden i Jeffrey Pressmanns og Aaron Wildawskys nu klassiske værk Implementation, der bærer den rammende undertitel: How great expectations in Washington are dashed in Oakland: or, Why it's amazing that federal programs work at all. For perspektivet i denne artikel er den afgørende pointe hos Pressmann og Wildawsky, at i særdeleshed opgaver og initiativer, der fordrer arbejde på tværs af almindelige forvaltningsgrene (såsom miljø, teknik og sundhed) uundgåeligt indeholder en kæde af beslutnings- og forhandlingsknudepunkter, der alle indebærer samspil mellem aktører med forskellige interesser og råderet over forskellige muligheder for at styre, ændre, bremse eller eventuelt helt stoppe gennemførelsen af en formuleret politisk målsætning. Selv i simple og gunstige situationer med ganske få beslutningspunkter samt endvidere med begrænset konfliktpotentiale er det derfor ofte ganske svært at udvikle og forankre virkningsfulde tværsektorielle samarbejder ikke mindst såfremt denne type af samarbejder 1) ikke synes strengt nødvendige for indfrielsen af formulerede politiske målsætninger samt 2) fremstår af marginal betydning for de involverede enheders samlede ressortområde.

Incitamentet og kapaciteten til tværsektorielt samarbejde - eller med et af tidens politiske plusord »partnerskabsbaseret samarbejde « - er derfor ofte af begrænset omfang. Denne situation gør sig ikke sjældent gældende i forbindelse med konkrete tiltag og større strategier på sundhedsfremmeområdet. ${ }^{35}$

Hermed rokkes dog ikke ved, at det umiddelbart ser lyst ud, for så vidt angår den almindelige vilje til at gøre brug af fysisk aktivitet som forebyggende og sundhedsfremmende middel.

Demonstrationsprojekter som »Odense - Danmarks Nationale Cykelby« antyder, at der i det mindste er interesse for at sætte ind overfor en varieret række af determinanter for fysisk aktivitet. Tilsvarende sikrer de nye reformer på folke- og gymnasieskoleområdet fortsat idræt en synlig position i skolelivet. Argumentet er her, at fysisk aktivitet på skoleskemaet nu og her medvirker til børn og unges trivsel samt på sigt etablerer grundlaget for sunde motionsvaner i voksenlivet.

Der findes altså forskellige markeringer af, at interessen er til stede for at gøre brug af fysisk aktivitet som et trivsels- og sundhedsfremmende middel. Ud fra et folkesundhedsperspektiv er det afgørende at anvende denne generelle interesse og bevågenhed til først og fremmest at nå de de- 
le af befolkningen, der muligvis gerne vil være fysisk aktive, men som af den ene eller anden grund har svært herved.

I bestræbelserne på at indløse denne målsætning, drejer det sig blandt andet om en aktiv intervention i de samfunds- og markedsgivne betingelser som mennesker lever under - herunder tiltag med fokus på miljødeterminanter for fysisk aktivitet. Den slags nyordninger stiller krav til sam-

\section{Noter}

1 F. Dela, 2004.

2 M. Kjær m.fl., 2000.

3 M. Aarnio m.fl., (2002).

4 M. Bønløkke, 2000.

5 European Commission, 2003.

6 WHO-Euro, 2002, p. 79-80. B.K Pedersen \& B. Saltin (red.), 2003.

7 European Commission, 2000. B. Jensen, P. Due, 2001. K. Larsen, 2003. For så vidt angår Knud Larsens artikel skal det for en god ordens skyld anføres, at samtidig med at det via denne reference kan godtgøres, at en betragtelig andel af børn og unge er inaktiv, dokumenterer artiklen ligeledes, at børn og unges deltagelsesgrad i organiseret idræt har været i vækst de sidste årtier.

8 Sundhedsstyrelsen, 2003.

9 Regeringen, 2003.

10 Regeringen, 2002.

11 Regeringen, 2002, p. 19.

12 Sundhedsministeriet 1999, sp. 47.

13 N. E. Sherwood \& R. W. Jeffery, 2000.

14 For en oversigt og diskussion af relevant litteratur vedrørende såkaldte miljødeterminanter for fysisk aktivitet henvises til Owen m.fl., 2000, Humpel, Owen \& Leslie, 2002, Craig m.fl. 2002, Dunn \& Blair 2002, Berrigan \& Troiano 2002, Giles-Corti \& Donovan 2003, Frank, Engelke \& Schmid 2003.

15 U. Christensen \& K. Albertsen, 2002, p. 209.

16 L. Iversen, 2004.

17 T. Pikora m.fl., 2003.

18 Vejdirektoratet, 2002a, 2002b. Persontransportarbejdet er udtryk for, hvor mange kilometer der tilbagelægges pr. person i Danmark.

19 Vejdirektoratet, 2001, tabel 5.10, s. 24

20 L. B. Andersen m.fl., 2000, s. 1621-1628. Hyppigheden af cykling til arbejde blev undersøgt hos fundsmæssige forandringer over en mangeårig periode. En afgørende opgave for samtlige parthavere - professionelle som lægfolk - der opfatter sig som involverede, er at holde beslutningstagere fast på en langsigtet strategi, som sikrer alle medborgere lige muligheder og betingelser for at $\varnothing$ ve indflydelse på de faktorer, der betinger sundhed og trivsel - herunder fysisk aktivitet.

783 kvinder og 6.171 mænd. Blandt disse døde 2.291 under opfølgningen.

21 K. Sælensminde, 2002.

22 Trafikministeriet, 2000, forord.

23 European Commission, 1998. ADONIS er forkortelsen for projektet med titlen: Analysis and development of new insight into substitution of short car trips by cycling and walking - how to substitute short car trips by cycling and walking. WALCYNG er ligeledes et EU-projekt, der dækker over titlen: How to enhance WALking and CYycliNG instead of shorter car trips and make these modes safer, 1998.

24 WHO-EURO, Cycling and health in cities (København, 2002).

25 Med udgangspunkt i sammenlignelige registreringer foretaget i 1995 cykler hver dansker gennemsnitlig $958 \mathrm{~km}$. pr. år. Tilsvarende cykler tyskeren $300 \mathrm{~km}$., franskmanden $87 \mathrm{~km}$., englænderen 81 $\mathrm{km}$. I EU cykler spanieren færrest med $24 \mathrm{~km}$. om året, hollænderen flest med $1019 \mathrm{~km}$.

26 Vejdirektoratet, 2001.

27 Dansk Statistik, 2000.

28 Transportrådet, 1999, s. 28.

29 Til sammenligning er der $300 \mathrm{~km}$. cykelsti i Københavns Kommune, som tre gange så mange potentielle brugere skal deles om set i forhold til Odense.

30 Carsten Jørgensen, 2000.

31 J. Troelsen, S. Underlien Jensen \& T. Andersen, 2004.

32 Andelen, der vurderede Odense som en god by at være cyklist i, var i 2001 og 2002 henholdsvis $73 \%$ og $80 \%$.

33 Gianni Stefanati, 1999.

34 A. Ritsatakis m.fl. Health impact assessment: An 
approach to promote intersectoral policies to reduce socioeconomic inequalities in health I: J. Mackenbach \& M. Bakke (Red.) Reducing in- equalities in health - a European perspective (London, 2002), pp. 87-88.

35 E. De Leeuw E \& T. Skovgaard, 2004.

\section{Litteratur}

M. Aarnio, T. Winter, U. Kujala, J. Kaprio: »Associations of health related behaviour, social relationships, and health status with persistent physical activity and inactivity: a study of Finnish adolescent twins«.. Br J Sports Med (2002), pp. 360364.

L. B. Andersen, P. Schnohr, M. Schroll, H.O.Hein: »All-Cause Mortality Associated With Physical Activity During Leisure Time, Work, Sports, and Cycling to Work«. Archives of Internal Medicine (2000).

D. Berrigan \& R. P. Troiano: »The association between urban form and physical activity in U.S. adults «. American Journal of Preventive Medicine (2002), pp. 74-79.

M. Bønløkke: »Skolernes motionsdag: En sundhedsfremmende indsats? « (Århus, 2000).

C. L. Craig m.fl.: »Exploring the effect of the environment on physical activity «. American Journal of Preventive Medicine (2002), pp. 36-43.

Dansk Statistik: »Persontransport 1997 - 1999« (København, 2000).

A. L. Dunn \& S. N. Blair: »Translating evidence-based physical activity interventions into practice «. American Journal of Preventive Medicine (2002), p. 8-9.

F. Dela: »Fysisk træning i behandlingen af det metaboliske syndrom «. Ugeskrift for Læger (2004).

European Commission: »ADONIS - Analysis and development of new insight into substitution of short car trips by cycling and walking - how to substitute short car trips by cycling and walking«. (1998).

European Commission: »Cycling: The way ahead for towns and cities «. (1999).

European Commission: »WALCYNG - How to enhance walking and cycling instead of shorter car trips and make these modes safer« (1998).

European Commission: »Report on the state of young people's health in the European Union« (2000).

European Commission: »Special Eurobarometer Physical Activity« (2003).

L. D. Frank, P. O. Engelke \& T. L. Schmid: »Health and Community Design - The impact of the built environment on physical activity« (Washington D.C., 2003).

B. Giles-Corti \& R. J. Donovan: »Relative influence of individual, social environmental and physical environmental correlates of walking «. American Journal of Public Health (2003), pp. 1583-1589.

N. Humpel, N. Owen \& E. Leslie: »Environmental factors associated with adults' participation in physical activity«. American Journal of Preventive Medicine (2002), pp. 188-199.

L. Iversen: »Forebyggelse af folkesygdomme - strategiske udfordringer«. Ugeskrift for Læger (2004), pp. 1537-1539.

B. Jensen B \& P. Due: »Børns motion, sundhed og trivsel«. I: P. S. Jørgensen m.fl. (red.) Sundhed på vippen - en undersфgelse af de store skolebørns sundhed, trivsel og velfard (København, 2001), pp. 106-118.

C. Jørgensen: »Cyklister i flok $\emptyset$ ger sikkerheden «. Cyklister, Dansk Cyklist Forbund (2000), nr. 1, pp 3-5.

M. Kjær. L. B. Andersen, I.K. Hansen: »Fysisk aktivitet hvilket minimum er tilstrækkeligt i et sundhedsmæssigt perspektiv«. Ugeskrift for Læger (2000), nr. 15.

K. Larsen: »Børns Idrætsdeltagelse 1987-1998«. I: Kulturministeriet, Bфrn og Unge i bevagelse - perspektiver og ideer (København, 2003).

E. De Leeuw E \& T. Skovgaard: »Utility-driven evidence for Healthy Cities: problems with evidence generation and application «. Social Science \& Medicine (in peer-review).

N. Owen m.fl.: »Environmental determinants of physical activity and sedentary behaviour««. Exercise and Sport Sciences Reviews (2000), pp. 153-158.

B. K. Pedersen \& B. Saltin (red.): »Fysisk aktivitet: håndbog om forebyggelse og behandling «. Sundhedsstyrelsen, Center for forebyggelse (2003).

T. Pikora m.fl: »Developing a framework for assessment of the environmental determinants of walking and cycling «. Social Science \& Medicine (2003), pp. 1693-1703.

J. Pressman \& A. Wildawsky: »Implementation« (Berkeley, University of California Press, 1973).

Regeringen: »Sund hele livet - de nationale mål og strategier for folkesundheden 2002-10«.. (København, 2002).

Regeringen: »Bedre sundhed for børn og unge «. (København, 2003).

N. E. Sherwood \& R.W. Jeffery: »The behavioural 
determinants of exercise: Implications for physical activity interventions «. Annual Review of Nutrition (2000), pp. 21-44.

G. Stefanati: »Ferrara: a city for cyclists «. I: Case Studies: Transport, environment and health in Europe: evidence, initiatives and examples (WHO, 1999).

Sundhedsministeriet: »Regeringens folkesundhedsprogram 1999-2008«. (København, 1999).

Sundhedsstyrelsen: »Oplæg til National Handlingsplan mod Svær Overvægt. (København, 2203)

K. Sælensminde: »Gang- og sykkelvegnett i norske byer. Nytte- kostnadsanalyser inkludert helseeffekter og eksterne kostnader av motorisert vegtrafikk «. (Oslo, 2002).

Trafikministeriet: »Fremme af sikker cykeltrafik - en strategi«. (København, 2000).
Transportrådet: »Dansk Transportforskning - status og visioner «. (København, 1999).

J. Troelsen, S.U. Jensen og T. Andersen: »Evaluering af Odense - Danmarks Nationale Cykelby«. (Odense, 2004).

Vejdirektoratet: »Nøgletal for transport 2002«. (København, 2002a).

Vejdirektoratet: »TU 1998-1999 - resultater fra transportvaneundersøgelsen «. (København, 2001).

Vejdirektoratet: »Årsbaserede nøgletal 1980-2001«. (København, 2002b).

WHO-Euro: »The European Health Report 2002«. (København, 2002). 